\title{
"CARA MENGAMBIL KEPUTUSAN YANG TEPAT UNTUK MEMILIH JURUSAN DAN PERGURUAN TINGGI YANG TEPAT PADA SISWA SMA DENGAN METODE ANALYTICAL HIERARCHY PROCESS (AHP)"
}

\author{
Fuji Rahayu Wilujeng* \\ Program Studi Teknik Industri, Universitas Bunda Mulia
}

\begin{abstract}
At this time, often encountered many students who feel wrong in choosing majors and the university even when they are already enrolled, it majors selected not according to their talents and interests. Early education of students and students will minimize the potential that they will feel disappointed with their choice when they are educated in college. Therefore, through community service activities is intended to provide education about how and step in selecting or determining the most appropriate option to continue their studies to pursue higher education. After this workshop, students feel very satisfied because they have an alternative keputuan in the selection of majors to continue to pursue higher education in accordance with their interests and talents.
\end{abstract}

Keywords: Analytical Hierarchy Process, making decisions

\begin{abstract}
ABSTRAK
Pada saat ini, sering dijumpai banyak mahasiswa yang merasa salah dalam memilih jurusan dan bahkan universitas ketika mereka sudah berkuliah, ternyata jurusan yang dipilih tidak sesuai dengan bakat dan minat mereka. Edukasi dini terhadap siswa dan siswi akan meminimumkan potensi dimana mereka akan merasa kecewa dengan pilihan mereka ketika mereka sudah mengenyam pendidikan di perguruan tinggi. Oleh karena itu, melalui kegiatan pengabdian kepada masyarakat ini ditujukan untuk memberikan edukasi mengenai bagaimana cara dan langkah dalam memilih atau menentukan pilihan yang paling tepat untuk melanjutkan studi ke jenjang perguruan tinggi. Setelah dilakukan acara workshop ini, para siswa merasa sangat puas karena mereka memiliki alternatif keputuan dalam pemilihan jurusan untuk melanjutkan ke jenjang perguruan tinggi yang sesuai dengan minat dan bakat mereka.
\end{abstract}

Kata Kunci: Analytical Hierarchy Process, AHP, pengambilan keputusan

\section{PENDAHULUAN}

Latar Belakang

Pengabdian kepada masyarakat adalah suatu proses pemberdayaan diri untuk kepentingan masyarakat. Pengabdian kepada masyarakat seharusnya bersifat kontinual dan jangka panjang karena dalam membangun sebuah masyarakat dibutuhkan proses yang sangat panjang. Banyak aspek yang harus disentuh untuk menjadikan suatu masyarakat itu menjadi baik, dari mulai karakternya, budayanya, sampai pola pikirnya untuk benarbenar menciptakan sebuah masyarakat yang beradab.

*email: fwilujeng@bundamulia.ac.id
Pengabdian kepada masyarakat merupakan salah satu unsur pokok didalam Tri Dharma Perguruan Tinggi selain Pengajaran dan Penelitian. Oleh karenanya melaksanakan pengabdian kepada masyarakat merupakan sebuah kewajiban bagi seorang dosen. Pengabdian kepada masyarakat merupakan bukti nyata bahwa sebagai insan akademisi, terutama dosen dituntut untuk dapat mengembangkan dan mengabdikan ilmunya kepada masyarakat dilingkungan sekitarnya. Peningkatan mutu para dosen tidak hanya berada pada lingkungan Perguruan Tinggi saja, tetapi juga terhadap masyarakat dan lingkungan sekitar. 
Pada saat ini, sering dijumpai banyak mahasiswa yang merasa salah dalam memilih jurusan pendidikan tinggi dan bahkan universitas ketika mereka sudah berkuliah, ternyata jurusan yang dipilih tidak sesuai dengan bakat dan minat mereka. Edukasi dini terhadap siswa dan siswi akan meminimumkan potensi dimana mereka akan merasa kecewa dengan pilihan mereka ketika mereka sudah mengenyam pendidikan di perguruan tinggi Dengan menggunakan analisa Analytical Hierarchy Process (AHP), memungkinkan untuk memberi analisa yang tepat guna menentukan pilihan jurusan pada perguruan tinggi yang paling tepat diantara sekian banyak alternatif yang ada. Pengadian kepada masyarakat ini diberikan kepada Siswa dan Siswi SMA kelas XI Sekolah SMA Mardiyuana Bogor.

\section{Tujuan dan Manfaat Kegiatan \\ - Tujuan umum :}

1. Memfasilitasi dan memperluas peluang bagi dosen dan mahasiswa untuk melaksanakan pengabdian kepada masyarakat dalam rangka memenuhi tugas dan fungsinya dalam bidang pengabdian kepada masyarakat

2. Membangun kerjasama dan kemitraan dengan masyarakat sebagai perwujudan dari pengembangan kompentensi sosial para dosen

3. Mempercepat upaya pengembangan masyarakat kearah dinamika masyarakat yang siap dan partisipatif dalam pembangunan intelektual guna mencapai perubahan - perubahan menuju perbaikan dan kemajuan, sesuai dengan nilai - nilai sosial yang berlaku di masyarakat.

4. Meningkatkan kepekaan civitas akademika terhadap masalah masalah intelektual dan sosial yang berkembang di masyarakat.

\section{- Tujuan Khusus :}

1. Meningkatkan kerjasama dengan masyarakat di SMA Mardiyuana.

2. Meningkatkan rasa kepedulian seluruh civitas akademik pada masyarakat, khususnya dalam hal edukasi dan pengembangan intelektual bagi siswa dan siswi di Jakarta dan sekitarnya.
3. Memberikan edukasi mengenai bagaimana cara dan langkah dalam memilih atau menentukan pilihan yang paling tepat diantara sekian banyak pilihan, dalam waktu dekat pelatihan ini dapat digunakan oleh siswa dan siswi untuk memilih jurusan dan kampus yang paling tepat untuk melanjutkan studi.

\section{- Manfaat :}

Manfaat kegiatan yang akan dirasakan oleh kedua belah pihak sebagai berikut :

1. Pihak institusi - Teknik Industri Universitas Bunda Mulia

a. Adanya wadah bagi dosen dan mahasiswa dalam mengaplikasikan keilmuan mengenai ilmu Teknik Industri

b. Adanya wadah dalam pelaksanaan kegiatan Tri Dharma Perguruan Tinggi

2. Pihak Komunitas Siswa Kelas XI SMA Mardiyuana

a. Memperoleh edukasi tentang bagaimana cara menentukan pilihan yang paling tepat dengan menggunakan analisa AHP

\section{METODE DAN PELAKSANAAN Metode}

Metode yang dipakai dalam pelaksanaan pengabdian kepada masyarakat kali ini adalah dengan menggunakan Analytical Hierarchy Process (AHP) yang bertujuan untuk menentukan pilihan yang paling tepat diantara sekian banyak pilihan dengan beberapa kriteria pada tiap pilihannya. Metode AHP (Analytical Hierarchy Process) dikembangkan awal tahun 1970-an oleh Thomas L. Saaty, dari Universitas Pittsburg.

Model AHP memakai persepsi manusia yang dianggap 'ekspert' sebagai input utamanya. Kriteria ekspert disini bukan berarti bahwa orang tersebut haruslah jenius, pintar, bergelar doktor dan sebagainya tetapi lebih mengacu pada orang yang mengerti benar permasalahan yang dilakukan, merasakan akibat suatu masalah atau punya kepentingan terhadap masalah tersebut. Pengukuran hal-hal kualitatif merupakan hal yang sangat penting mengingat makin kompleksnya permasalahan di sekitar kita dengan tingkat ketidakpastian yang makin tinggi. Selain itu, AHP juga 
menguji konsistensi penilaian. (Juliyanti dkk, 2011).

Menurut Saaty (1994), pada Analytic Hierarchy Process terjadi penyusunan permasalahan ke dalam suatu struktur hirarki sehingga pengambil keputusan semaksimal mungkin dapat melibatkan semua faktor yang perlu dipertimbangkan dan akan terlihat jelas kaitan antara faktor yang satu dengan yang lain. Susunan model hirarki pada metode AHP ditunjukkan pada Gambar 1.

Untuk menilai perbandingan tingkat kepentingan elemen, Taylor (2008) menetapkan skala kuantitatif 1 sampai 9. Nilai dan definisi pendapat kualitatif dari skala prefensi untuk perbandingan berpasangan ditunjukkan pada Tabel 1.

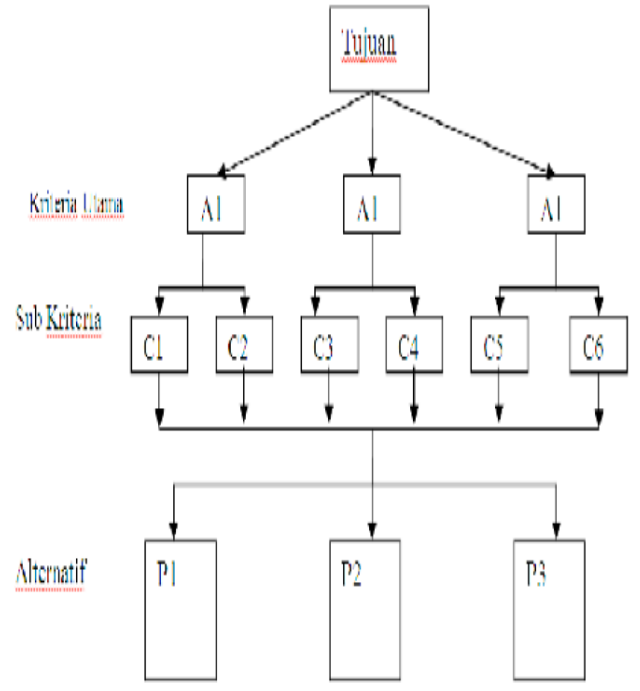

Gambar 1. Susunan Hirarki

Tabel 1 Skala prefensi

\begin{tabular}{|l|l|}
\hline Tingkat Preferensi & $\begin{array}{l}\text { Nilai } \\
\text { Angka }\end{array}$ \\
\hline Sama disukai & 1 \\
\hline Sama hingga cukup disukai & 2 \\
\hline Cukup disukai & 3 \\
\hline Cukup hingga sangat disukai & 4 \\
\hline Sangat disukai & 5 \\
\hline $\begin{array}{l}\text { Sangat disukai hingga amat } \\
\text { sangat disukai }\end{array}$ & 6 \\
\hline Amat sangat disukai & 7 \\
\hline $\begin{array}{l}\text { Amat sangat disukai hingga luar } \\
\text { biasa disukai }\end{array}$ & 8 \\
\hline Luar biasa disukai & 9 \\
\hline
\end{tabular}

Dikutip dari Yulianti (2011), langkah langkap dalam pengambilah alternatif dengan menggunkan metode AHP digambarkan dalam diagram alir pada Gambar 2.

\section{Pelaksanaan}

Pelaksanaan pengabdian kepada masyarakat ini dilaksanakan di SMA Mardiyuana Bogor. Peserta yang mengikuti pelatihan adalah siswa dan siswi SMA kelas XI. Pelaksanaan workshop bisa dilihat pada Gambar 3 dan 4. Awal pelaksanaannya diawali dengan cara menggali informasi mengenai jurusan apa yang paling diminati siswa SMA Mardiyuana, setelah dilakukan identifikasi, ternyata mayoritas dari mereka memiliki kendala mengenai minimnya informasi mengenai pemilihan jurusan yang tepat sesuai skill dan kemampuan mereka.

Dari permasalahan tersebut, kemudian prodi berinisiatif memberikan informasi tentang jurusan-jurusan yang paling diminati di perguruan tinggi di Indonesia serta besarnya peluang kerja dari jurusan tersebut. Kemudian dengan metode AHP dibuat kriteria untuk jurusan yang akan diambil.

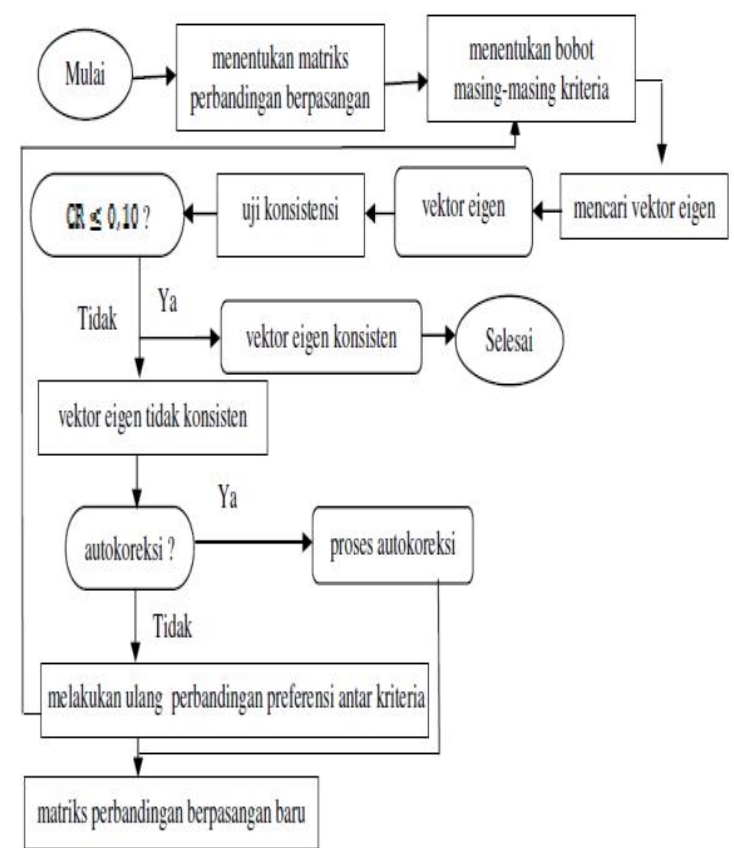

Gambar 2. Bagan alir proses metode AHP

\section{Metode Penyampaian}

Penyampaian materi akan dilakukan secara interaktif di dalam kelas SMA Mardiyuana. Peserta akan ditemani sejumlah asisten mentor (merupakan mahasiswa Teknik Industri Universitas Bunda Mulia). Selanjutnya, asisten mentor akan mengawal dan mengawasi siswa dan siswi dalam mengerjakan perhitungan menggunakan 
metode AHP dari awal sampai proses penarikan kesimulan.

Ada seorang instruktur yang memandu dan melakukan presentasi di depan kelas tenatng bagaimana yang mengerjakan perhitungan dengan metode AHP. Jika ada peserta yang mengalami kesulitan, mentor dan instruktur akan secara langsung memberikan respon.

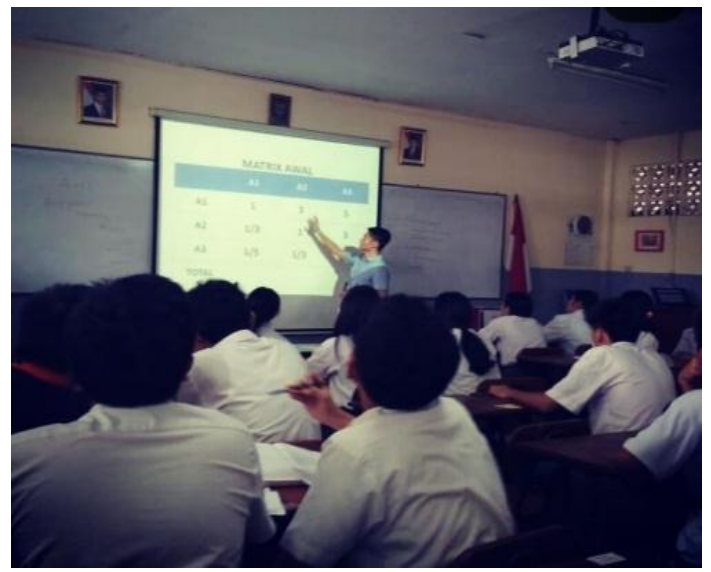

Gambar 3 Proses pelaksanaan workshop

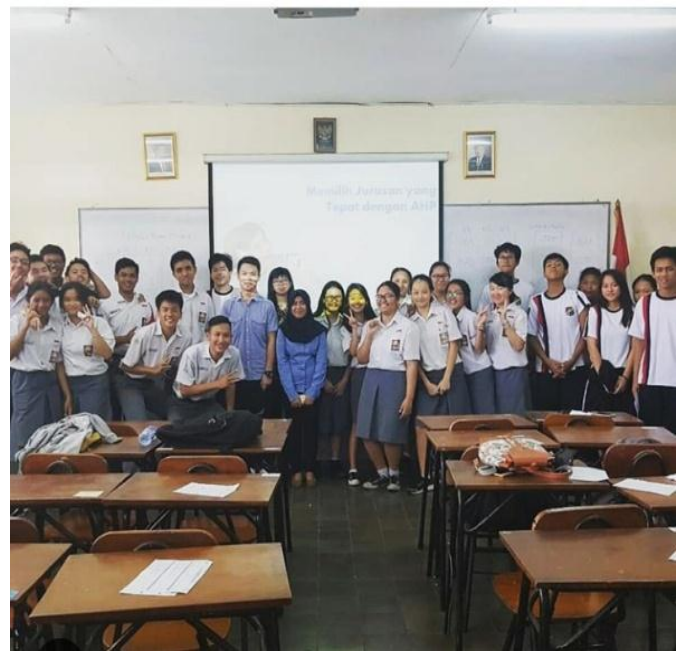

Gambar 3 Foto bersama pada sesi acara

\section{HASIL DAN PEMBAHASAN}

Setelah dilakukan workshop secara interaktif tentang dengan menggunakan analisa Analytical Hierarchy Process (AHP), siswa dan siswi SMA Mardiyuana dapat menentukan pilihan jurusan pada perguruan tinggi yang paling tepat sesuai minat dan skill mereka.

Pada perhitungan metode AHP, kriteria untuk pemilihan jurusan pada perguruan tinggi yang dipakai ada tiga, yaitu banyaknya peluang kerja, biaya yang diperlukan untuk kuliah pada jurusan tersebut dan kemudahan lulus. Kriteria yang diambil ini berdasar dari tren analisis alternatif pilihan yang saat ini banyak diminati dan berdasar dari keputusan seseorang yang expert dalam bidangnya.

Sedangkan alternatif jurusan yang dipilih diambil dari jurusan yang ingin mereka ambil sesuai dengan keinginan dan skill dalam diri peserta masing - masing. Dari sekitar 40 peserta dari siswa dan siswi kelas XI SMA Mardiyuana, hasil alternatif jurusan $40 \%$ mayoritas dari mereka ingin mengambil jurusan teknik, $30 \%$ ingin mengambil kedokteran dan kesehatan, $20 \%$ ingin mengambil bidang sains dan $10 \%$ lainnya ingin mengambi di luar dari bidang yang telah disebutkan di atas.

Setelah dilakukan acara workshop ini, para siswa merasa sangat puas karena mereka memiliki alternatif keputuan dalam pemilihan jurusan yang sesuai dengan minat dan bakat mereka. Selanjutnya, pada akhir sesi acara, mentor akan memeberikan kuesioner penilaian kepada peserta untuk menilai kegiatan hasil pengolahan data akan memberikan masukan dan informasi bagi prodi untuk menganalisa dan evaluasi kegiatan serupa dikemudian hari. Hasil pengolahan umpan balik dari kuesioner dapat dilihat pada Tabel 2 dan Gambar 4 di bawah.

Tabel 2. Hasil perhitungan kuesioner umpan balik

\begin{tabular}{|c|c|c|}
\hline No. & Pertanyaan & $\begin{array}{c}\text { Rata-rata } \\
\text { nilai hasil } \\
\text { umpan } \\
\text { balik } \\
\text { (skala 1-4) }\end{array}$ \\
\hline \multicolumn{3}{|c|}{ A. MATERI DAN IMPLEMENTASI } \\
\hline 1 & $\begin{array}{l}\text { Manfaat materi bagi } \\
\text { peserta }\end{array}$ & 3.38 \\
\hline 2 & $\begin{array}{l}\text { Relevansi materi dengan } \\
\text { tujuan kegiatan }\end{array}$ & 3.15 \\
\hline 3 & $\begin{array}{l}\text { Ketepatan media atau } \\
\text { sarana yang digunakan oleh } \\
\text { narasumber }\end{array}$ & 3.10 \\
\hline 4 & $\begin{array}{l}\text { Proses atau kegiatan } \\
\text { pelaksanaan }\end{array}$ & 3.18 \\
\hline 5 & $\begin{array}{l}\text { Penambahan pengetahuan } \\
\text { /keterampilan yang dapat } \\
\text { diaplikasikan }\end{array}$ & 3.23 \\
\hline \multicolumn{3}{|c|}{ B. INSTRUKTUR / NARASUMBER } \\
\hline 1 & $\begin{array}{l}\text { Kemampuan atau } \\
\text { penugasan terhadap materi }\end{array}$ & 3.18 \\
\hline 2 & $\begin{array}{l}\text { Kemampuan dalam } \\
\text { menyampaikan materi }\end{array}$ & 3.26 \\
\hline 3 & Kemampuan menggunakan & 3.22 \\
\hline
\end{tabular}




\begin{tabular}{|l|l|c|}
\hline & $\begin{array}{l}\text { metode yang tepat dengan } \\
\text { materi }\end{array}$ & \\
\hline 4 & $\begin{array}{l}\text { Kemampuan dalam } \\
\text { menjawab pertanyaan } \\
\text { peserta }\end{array}$ & 3.17 \\
\hline 5 & $\begin{array}{l}\text { Kemampuan menciptakan } \\
\text { suasana yang mendukung } \\
\text { kegiatan }\end{array}$ & 3.19 \\
\hline
\end{tabular}

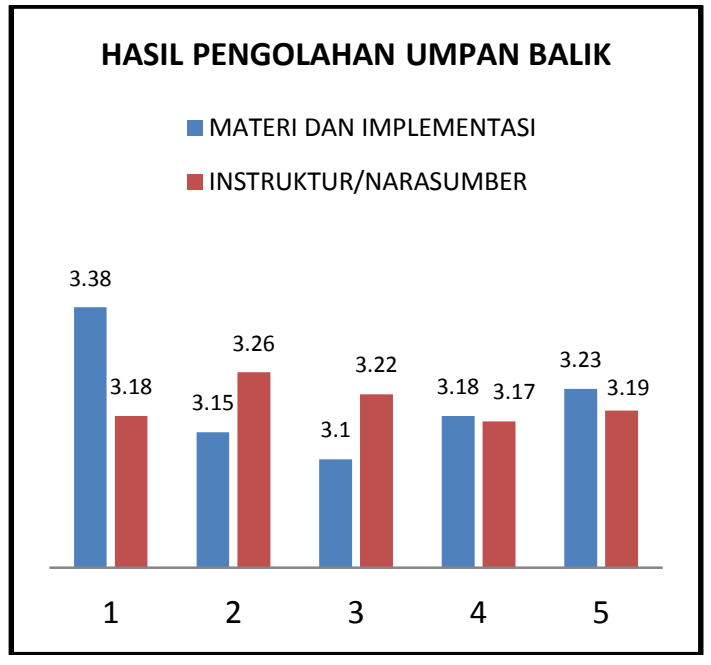

Gambar 4. Diagram batang kuesioner umpan balik

\section{SIMPULAN}

Simpulan yang bisa diperolah dari kegiatan ini antara lain :

1. Para siswa jadi lebih yakin dalam menentukan pilihan jurusan pada perguruan tinggi yang paling tepat sesuai dengan minta an bakat mereka.

2. Kegiatan ini sangat membantu dan cukup efektif dilakukan untuk para siswa yang akan melanjutkan ke jenjang perguruan tinggi.

Saran dari kegiatan ini adalah :

1. Karena kegiatan ini membutuhkan proses perhitungan panjang dari metode AHP, maka perlu kesiapan mentor yang mendampingi peserta untuk membantu proses perhitungan karena dikhawatirkan ada peserta yang tiak mengerti proses perhitungannya.

2. kegiatan ini memerlukan waktu yang panjang dengan proses perhitungan yang sedikit rumit jika dilakukan manual. Untuk kedepannya jika memungkinkan bisa dilakukan dengan bantuan penggunaan software pengambilan keputusan, seperti expert choice.

\section{DAFTAR PUSTAKA}

Saaty, T.L., B. Yuan .1994. The Analytic

Hierarchy Process. McGraw-Hill, NewYork.

Taylor, B.W. 2008, Edisi 8. Introduction To Management Science, Salemba Empat. Jakarta.

Juliyanti, Irawan, Muklash .2011. Pemilihan Guru Berprestasi Menggunakan Metode AHP dan Topsis. Prosiding Seminar Nasional Penelitian, Pendidikan dan Penerapan MIPA, Universitas Negeri Yogyakarta. 